\title{
THE DEBATE ON PRUDENCE IN ACCOUNTING
}

\section{Hristina Oreshkova ${ }^{1}$}

\begin{abstract}
In support of the critical analysis targeted at substantiating the necessity of reintroducing "prudence" in the Conceptual Framework for Financial Reporting (CF), that is the primary author's goal, the article provides further results as well as views and arguments, based on research, provoked by the International Accounting Standards Board's decision to revise the CF (in September 2010) and remove "prudence" in favour of "neutrality" regarded as a qualitative characteristic. The author's aim is not to discuss the role of the CF as a whole, or its objectives, but to contribute to the current debate on a complicated and highly controversial issue, raised in the Discussion Paper ${ }^{2}$ (DP), followed (in January 2014 and May 2015) by the Exposure Draft (ED) containing proposals for a revised CF.

The thesis held by the author, both before and now, is that for a considerable number of reasons it is imperative to restore "prudence" in the CF, subjected to revision at the moment (and yet expected) as an introduction to the International Accounting Standards (IAS)/International Financial Reporting Standards ${ }^{3}$ (IFRS), with a clearly defined content of its definition in order to avoid misinterpretation or misunderstanding, which, in my view, will not impair "neutrality", but will support it.

On the basis of my long-lasting research alongside the thorough observation of the regulatory process, I would argue that as a supranational body, developing the accounting norms for many business entities operating in the EU and elsewhere, the EU accounting standards setter, who is responsible for the ambiguities or at least misconception, due to its prerogatives, has not been consistent in its policy with regard to prudence over the years. Probably one major reason is the influence of political, institutional and other factors in the global process of convergence. The development and deliberations as of December 2016 and January and February 2017 as to the revision of the CF have convincingly confirmed that once more.
\end{abstract}

JEL Classification Numbers: M41; M14; DOI: http://dx.doi.org/10.12955/cbup.v5.949

UDC Classification: 657

Keywords: Financial reporting; prudence; conservatism; neutrality; hidden reserves; deliberate bias; transparency

\section{Introduction to the Debate on Prudence}

Over the past decade, countries in Europe have experienced changes in financial reporting described as "a revolution" . Undoubtedly, the political decision on the IAS adoption by the EU Member States from January 1st, 2005 was a challenge for institutional and professional organizations, national and supranational bodies of authority, and many people at different levels of corporate governance and management. However, a year after the IAS adoption, an EC-sponsored study has found that the adoption of IFRS has proved to be ultimately successful. The study concluded that "there was widespread agreement that IFRS has increased the comparability of financial statements across countries, across competitors within the same industry sector and across industry sectors."

Long before, and until now, prominent scientists in Europe and overseas have remained indifferent to the enthusiasm of that change even skeptical about its benefits. Insusceptible to the inspired rhetoric of others, Professor Jacques Richard accused EU regulatory institutions for non-applying, avoiding, or adapting accounting principles through compromises in regulations, in favor of particular interests (November 2005, Le Monde diplomatique, no.1:24-25). Now that countries are slowly and unsteadily recovering from the consequences of the last global economic crisis on an unprecedented scale it is unlikely for such an insight to remain unnoticed even by opponents.

In the dispute focused on the nature of the reasons for the profound changes in EU financial reporting, as well as on the essence of the factors that influence the rulemaking and regulatory processes and their efficiency, researchers, experts, specialists are not unanimous - the conclusions and forecasts point to more than one perspective while the estimates range from positive to extremely negative.

Since September 2010 the discussions have significantly intensified due to the fact that the IASB has revised the first chapters of the CF and replaced "prudence" with "neutrality" regarded as a qualitative characteristic. The crucial question was whether it was just a matter of linguistic means of expression

\footnotetext{
1 Hristina Georgieva Oreshkova, Associate Professor, D-r Hristina Oreshkova, Faculty of Finance and Accounting, University of National and World Economy, Sofia, Bulgaria, e-mail: hristina_oreshkova@abv.bg

2 IASB IFRS Foundation (July 2013). Discussion Paper 'A Review of the Conceptual Framework for Financial Reporting'.

${ }^{3}$ In the present article 'International Accounting Standards (IAS)' and 'International Financial Reporting Standards (IFRS)' are used as equivalents.

${ }^{4}$ Hoogervorst, H. (2012), "The Concept of Prudence: dead or alive?", FEE Conference on Corporate Reporting of the Future, Brussels, pp. 1-7 (p. 1).
} 
or a change that undermines the essentials of financial reporting. Maybe under some political pressure, major progress was made at that point to the global consistency, or more likely towards the further erosion of "Prudence" in accounting.

Thus, the foremost author's goal is to justify the necessity of restoring 'prudence' into the CF, and to consistently support that view by sound and cogent arguments. I should specify at this point, that 'prudence' should not be considered a qualitative characteristic of financial statement information even less a basic assumption as it was settled in previous texts of the CF. My key observation should be emphasized: 'Prudence' may be thought about as a fundamental principle, as a core principle, as a guiding principle, as a major requirement, as an essential theoretical concept underlying financial accounting. However, it should not be regarded as a qualitative characteristic of information provided by financial statements of general purpose as it was previously stated in the CF. It is deeply erroneous from a theoretical perspective, in my view. 'Prudence' is, and should be regarded as the primary principle amongst all the traditional accounting principles, to which professional accountants, predominantly analytical and conservative people, i.e., more pessimistic rather than optimistic, have been closely attached for centuries.

By design, not by chance, the article focuses on a rich palette of reasoning from various academic viewpoints. It is subordinate to the author's objective to reveal in an explicit manner the fundamental and complex nature of the issue of prudence. Due to that circumstance, eminent authors of the past even of the present has dedicated fundamental research to 'prudence'; that is an undeniable fact which cannot be overlooked; moreover, it should be emphasized, and regarded as an author's observation of crucial importance for structuring the article, and for future surveys.

Another important objective is to differentiate the author's view regarding 'prudence' as an overriding principle of accounting from opinions inclined to undervalue its importance, and from other more extreme interpretations.

The terminology of the article is mainly in the field of financial accounting and reporting under the Conceptual Framework, the IAS/IFRS, and the interrelated European Directives. The structure of the article is subordinated to the author's objectives and the regular systematic requirements.

The heuristic methods of knowledge as analysis and synthesis, induction and deduction, comparison, analogy, observation, descriptive method etc. applied for achieving the author's goal are generally accepted for research in that scientific field, and are commonly used due to their universal nature and the predictable results.

\section{Different Even Conflicting Academic Views on Prudence: A Literature Background}

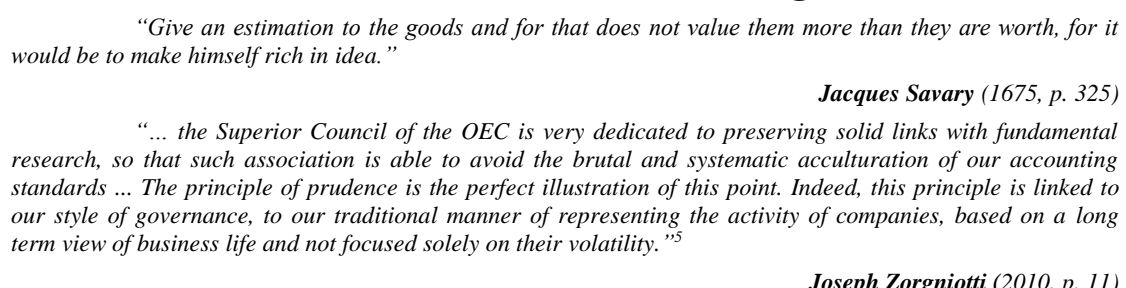

The principle of prudence or 'conservatism' in accounting, as it is mostly understood in Continental Europe, for instance, Germany and France, or the concept or convention of conservatism as it is interpreted in the UK and the USA, respectively, has been the subject of a heated debate for decades now. I consider Professor Barker's distinction to be valuable from a theoretical viewpoint, although I use both of the terms as it is done in the context of the relevant research depending on the author's understanding. I believe that this is necessary for the sake of expression and clarity in order to attain precision, admitting that I lend priority to prudence. My motive is based on a solid foundation. The conceptual ideas of prudence have long been ingrained in our accounting system, culture and tradition as it has been developed under the influence of the Continental European accounting doctrine.

Perceived and defined either as a principle or a concept, it is more than obvious that 'prudence' raises a highly controversial issue for both researchers and practitioners. Due to a long-lasting thorough observation of the regulatory process, I can reasonably argue that the EU accounting standards setter,

\footnotetext{
${ }^{5}$ Zorgniotti, J., (2010), Turn accounting into a meaningful art, The First Symposium on accounting research, ANC, Paris.
} 
who is responsible for the ambiguities or at least misconception by virtue of its prerogatives, has not been consistent in its policy with respect to prudence. The recent development and deliberations as of December 2016 and January and February 2017 as to the revision of the CF have convincingly confirmed that once more.

The fundamental research, dedicated to prudence or 'conservatism', reveal different even antagonistic academic views. Considerations are mostly focused on the concepts evolving over time, the essence of the traditional or 'conventional' prudence or 'conservatism', and the inherent rules that must be specifically applied in the process of valuation under the imperative of the prudence principle if it is embraced as a primary one. It should be noted that essential theoretical and practical issues of valuation and of entity's accounting policy are mainly discussed with respect to prudence or 'conservatism.' Most of the surveys focus on the issues of recognition and subsequent valuation and disclosure of items which would create difficulties, since an estimation is necessary; in other words, the surveys predominantly treat complicated matters in which the recognition of an item implies an unbiased, unprejudiced, best possible estimate; usually this is due to an item's specifics and significant uncertainties that give rise to measurement, methodological and disclosure problems. My understanding of 'uncertainty' in the case is that 'uncertainty' means that any carrying amount under consideration is (or should be regarded as) an estimate that would be difficult to verify, since there is a place for significantly subjective judgement in determining either the initial cost or the carrying amount (value) of an element at the balance sheet date. The subjective judgment can be carefully made; however, it is always hardly verifiable for authenticity as it may be presumed. It is a matter of expertise, professionalism including ethics, and responsibility.

Such problems usually arise in an attempt to look for the most appropriate treatment alongside the search for the most reliable evaluation of an element for its recognition in financial statement; they may refer to a wide range of items, varying in nature and types, as assets and liabilities, expenses and revenues or income, profits and losses, and others; to be specific, among the emblematic examples are: research and development (R\&D) costs, also known as expenditure on $\mathrm{R} \& \mathrm{D}$, costs of litigation, borrowing costs, advertising costs (or expenses), costs of luring new clients, some kinds of intangibles, internally generated goodwill, provisions for restructuring or of another type, contingencies, acquired goodwill and many others; the possible effects of a particular accounting approach or model of initial or subsequent evaluation on the carrying amount of (net) assets and income are mostly discussed in respect of the issue of the "hidden reserves". The problem has been raised, and, in my opinion, has been exaggerated by opponents claiming to be against prudence or 'conservatism', who appear to be advocates of the "true and fair view" or "fair presentation" postulate; the appropriate level of being cautious from the perspective of accountants as practitioners is also often in the focus of researchers and discussions. For example, scientists investigate how the degree of accounting conservatism, reflected in the financial statements information of European companies, evolves over time during long periods, and how the adoption of IAS/IFRS has influenced the differences in the degree of balance sheet conservatism and earnings conservatism between European companies reporting under IAS/IFRS. Most influential authors like Sudipta Basu (2009) describe how their contemporary research on the origins of accounting, including Chinese accounting, is related to their search for an ultimate explanation for conservative accounting.

All these essential issues are exclusively identified with respect to 'prudence'; thus they should be discussed not in a prejudiced or manipulative manner, but in a straightforward one, not forgetting the rationality that the traditional, i.e. 'conventional' prudence embodies. We confidently believe that the resilience of prudence to criticisms over time is due to its fundamental nature as a core principle and its crucial role in accounting as a unity of theory, methodology and social practice for centuries.

One major observation should be taken into consideration primarily. In my view, it is of great importance to underline that a difference should be made between two cases: the first case is when the creation of hidden reserves is being systematically made in a deliberate manner, on purpose; that is the case when one is not faced with whatever kind of uncertainty and can ascertain the actual facts or values without difficulty; the second case is when hidden reserves are created not deliberately, but accidentally, unintentionally, involuntarily, in the absence of any deliberate actions; that is the case when one is faced with some kind of uncertainty or unknown magnitudes. The deliberate creation of hidden reserves and 'conservatism' are mistakenly equaled, in my opinion; they seem to be similar, 
but it is just ostensibly; such an interpretation implies a superficial view on the problem; however, there is a line that helps to differentiate between the two types of behaviour of accountants. Following that way of thinking, at this point it is appropriate to support our reasoning by Paton and Stevenson's understanding that, in my view, is perfectly correct and truthful:

"Conservatism is a genuine, prudent response to uncertainty, whereas the "big bath"
accounting is a deliberate attempt to mislead the users of financial statements
information when there is in fact no uncertainty. W. A. Paton clearly pointed out that
"a sheer understatement where it is possible to ascertain the actual facts is not
conservatism but concealment" (1916, p. 237; Emphasis added).

Some present-day views on conservatism in accounting, and understandings existing for decades, do not seem to include or permit any deliberate, that is, intentional manipulations in valuation of items, or other abuses with opportunities in accounting as a system, which to be targeted at understating income in a current period, and overstating income in future periods, if there is no or there is just a little economic uncertainty surrounding transactions. In the USA, the accountants' behavior in favor of the creation of hidden reserves in a prejudiced manner is known as "a big bath" accounting, and such behavior is thought about as inconsistent with the principle of conservatism. It is confirmed, for instance, by the US FASB's view as of 1980 towards conservatism and hidden reserves exposed in the FASB Framework as of 1980. In that Framework, the US accounting standards setter emphasizes that 'conservatism in financial reporting should no longer connote deliberate, consistent understatement of net assets and profits (FASB, para. 93)'. At the next point, in para. 95, the US FASB underlines that 'conservatism no longer requires deferring recognition of income beyond the time that adequate evidence of its existence becomes available or justifies recognizing losses before there is adequate evidence that they have been incurred' (US FASB Framework, 1980, para. 95).

The recent decades' tendency of opposing conservatism, and of contradicting its supporters in some circles, in favor of the so-called 'true and fair picture' or 'true and fair view,' or 'true and fair presentation' is well known. It can be confirmed by a quote revealing the judgment of a Professor in finance: 'Conservatism is under attack ... some ... even the FASB ... are now suggesting it may be better to abandon conservatism ... to show more unbiased financial statements.' Besides that, it is the standpoint of eminent scientists in the field of accounting and economics from France, Spain, the UK, Germany, the USA etc., such as Professor Jacques Richard, Professor Jesús Huerta de Soto Ballester, Professor Stella Fearnley, Dr. Carsten René Beul, Professor Shyam Sunder, and many others, and at this point I will admit, that my perspective and opinion are the same as well.

However, on the grounds of my research so far, I confidently believe that, especially in Continental Europe, the principle of prudence or 'conservatism' has been an integral part of financial accounting essentials for a long period of time, and it can hardly be disproved, in my view. One major argument which is put forward by the adherents in this respect is that prudence or 'conservatism' serves well the needs of creditors. With a specific allusion to the German accounting system, Haller (2003, p. 92) states that the principle of conservatism is not understood as a sub-characteristic as it is understood in the USA ${ }^{6}$ and in the UK but rather as the core principle of accounting which stems logically from the objective of protecting creditors (following Hellman, 2008, p. 72). At this point, it should be noticed that conservatism also serves well many other stakeholders, such as potential and present investors, employees and other people in employment, institutions of state authority, as well as the social interests of all society members and the society as a whole, due to its social significance and the favorable societal implications of its consistent application.

Haller (2003, p. 108) continues the explanation with the argumentation as follows: 'The idea of safeguarding the company as a source of income generation ... with the function of the balance sheet in calculating taxable income, leads to an emphasis on capital preservation ... The concept of the preservation ... of nominal equity ... is also the reason for the importance of the principle of prudence, which, in line with the specific author's wording, leads to the use of the so-called hidden or 'secret' reserves ... counterproductive in an accounting model whose only objective is to give information

\footnotetext{
${ }^{6}$ However, Sterling (1967) argues that conservatism has historically been one of the most influential accounting principles even in the USA, where companies to a greater extent turn to the stock market for financing.
} 
because secrecy is the opposite of information. ${ }^{77}$ However, it is admitted that: 'In a model which stresses prudent income calculation with the objective of the preservation of capital and an underlying concept of creditor' protection ... it is a very logical approach' (by Hellman's notes, 2008, p. 97). In my view, the ultimate thought seems to be truthful and realistic. However, the hidden or 'secret' reserves in themselves cannot be regarded as an instrument or tool for deliberate manipulations aimed at understatement of value of (net) assets or income. Initially, in their origin, hidden reserves are rather the consequence or the effect that might be caused by non-professional approach to valuation process, lack of expertise, more or less impact of stakeholders at a higher management level, other factors of influences etc.; moreover, the biased misstatements of values of financial statement elements when it is not difficult to ascertain the real facts, should be regarded not as conservatism but simply as concealment of data, which in its turn can be misleading. But this is not always the case in practice.

Similar is the view held by Professor Hellman (2008, p.74). He reasonably argues that a long tradition of accounting conservatism exists, predominantly in code-law-based countries. Professor Hellman refers to Haller and Eierle (2004, p. 36), who suggest that it has been a received wisdom in Germany that conservative accounting is '... the best way to reach the objective of creditor protection'. Creditors' preference for conservatism is explained as a way of protecting the priority of the creditors' claims above the shareholder claims (J. M. G. Lara and A. Mora, 2004, quoted by Hellman; Emphasis added). For that reason, it is argued, that the determination of non-restricted equity, that is, funds which are distributable among shareholders, has been much emphasized on in code-law-based countries. With specific regard to Swedish legislation, K. Artsberg and C. Nilsson (1993, p. 37), suggest that the view, incorporated in the Swedish legislation, is that 'a single good year should not result in dividends, but that profits shall be retained as reserves for the future' (K. Artsberg and $\mathrm{C}$. Nilsson, 1993, p. 37; quoted by Hellman; Emphasis added).

On the basis of my investigations so far it can be suggested that in Germany, France, Sweden and other European countries, for a long period of time conservatism was the overriding accounting principle. It still appears to be an essential theoretical concept especially in Continental European countries. Unfortunately, in Professor Jacques Richard's view, the IFRS ... embody a systematic and all-out assault on a fundamental principle underlying accounting (already fairly well eroded throughout the $20^{\text {th }}$ century) - the principle of prudence, which forbids statements of potential profits and prescribes disclosures of potential losses (by Professor Jacques Richard; Emphasis added).

Although the influence of the IASB's policy has been powerful for decades, in practically oriented discussions, the principle of prudence is mostly deliberated on in respect of accounting issues arising from uncertainty. Debates on issues of how exactly the principle is being applied in reality regularly arise and they are usually focused on critical questions as, for example, whether particular accounting solutions can be regarded as enough conservative, i.e., prudent and sensible.

Hellman $^{8}(2008$, p. 74$)$ reasonably argues that the strong connection between accounting and taxation in code-law-based countries also tends to work in favour of conservatism, and this is quite logical as it may be presumed that more prudent valuations of assets and liabilities would also lead to lower taxable income. It may be noticed here that it is not necessarily be always so. Taxable income can be calculated depending on specific rules of tax laws designed to regulate the process of transformation of reported financial results for the purposes of taxation. Even accounting losses, not only profits, are subjected to procedure of tax transformation, in order to counteract possible management propensity of creating hidden reserves, or, to neutralize to a certain extent the effects of such practice.

Conservatism is broadly considered to be a tendency of accountants' behavior of preferring to choose, when faced with some kind of uncertainty as to specific events, to attribute lower estimates of values of assets and revenues, and conversely, higher estimates of values of assets and expenses. It is commonly deliberated that conservatism stipulates that expenses and liabilities are not understated in accounts and consequently in financial statements, and on the contrary, assets and revenues are not overstated in financial statements. In Sterling's view (1967) conservatism seems to be closely related

\footnotetext{
${ }^{7}$ The hidden or 'secret' reserves are considered to be the feature of the German accounting and for the reason of that it has been criticized for long in an international context.

${ }^{8}$ Moreover, in Hellman's view, auditors also may have a conservative bias, since they are not expected to get sued on the grounds of financial statements, being too conservative (Hellman, 2008, p. 74)
} 
to the concept of realisation, as conservatism implies that a profit should not be recognized, before it is realized. The approach of recognition of profit in advance, before it is realized, always poses to risks, more or less, and it may prove to be overly unrealistically optimistic. Thus, as early as1967, Sterling reasonably suggests that conservatism may in fact be the root of the principle of realization. That view is supported by emeritus professors of accounting, such as the French Professor Jacques Richard and many, many others. The debate is still going on and has strongly intensified during the last global economic crisis. The distinction between realized and unrealized profits should be clear to all interested parties, and that view has been predominantly sustained over time.

Scientific and historical evidence confirms that conservatism has been one of the oldest and most important principles of accounting (Sterling, 1967; Watts, 2003a). However, a lot of researchers have found that it has been problematic to completely incorporate conservatism in the normative theory of accounting. Conservatism was a primary principle for the German supporters of the balance sheet approach, known as 'statists' (Forrester, 1993, Chapter V). Since 1908 and on, a different view and an income statement approach have been propounded (Schmalenbach's theory, 1959, and Quire, 1965, emphasizing the 'matching of flows of production and consumption in order to measure profit'). Although Schmalenbach disagreed with the static theory, he agreed with the statists with regard to the primary role of conservatism. Schmalenbach $(1959, p$. 82) argued that an overstated profit is far more dangerous than an understated one. However, at the same time, Schmalenbach (1959) admitted that conservatism can be exaggerated and he also presumed that understatement of profits can be harmful (Hellman, 2008, p. 74; Emphasis added). By Hellman's specific wording, it is not clear-cut from reading Schmalenbach (1959) how the appropriate level of conservatism should be determined.

Researchers such as Paton and Littleton (USA, 1940) propounded an extremely different view. These authors intended to construct a framework of an accounting theory conceived as 'a coherent, coordinated, consistent body of doctrine' (1940, p. ix), of which conservatism should not be a part. They regarded conservatism only as an attitude to be added when interpreting the accounting numbers (Littleton, 1940, p. 128), and as 'a rule of caution' applied by users when interpreting the results of accounting measurements made according to 'a coherent body of doctrine.' However, that view has not been acknowledged in practice. In this respect Sterling (1967) argues that whenever conservatism clashes with a conventional accounting principle (for example, the valuation of inventory at the lower of cost or market value or simply at historical cost, in Sterling's way of expression at the time) there is a preference for the more conservative policy in practice (by Hellman, 2008, p. 75), hence the more conservative accounting approach and method of valuation. A conclusion can be drawn that these differentiating views demonstrate problems of delimiting conservatism to some 'appropriate' level. Then the critical question immediately arises, which is the most 'appropriate' level of conservatism.

For researchers in the normative accounting tradition, the application of the principle of conservatism has been understood as theoretical (Hellman, 2008, p. 75). Hendriksen (1982, p. 81) argues that the general constraint arising from uncertainty has served as a basis for the traditional accounting concept of conservatism. However, the idea of systematically understating assets and overstating liabilities, recognizing revenues too late and of expenses too early has been interpreted by critics belonging predominantly to the Anglo-American tradition as a way of reducing the relevance of accounting information. In the words of Hendriksen $(1982$, p. 83) 'conservatism is, at best, a very poor method of treating the existence of uncertainty in valuation and income. At its worst, it results in a complete distortion of accounting data.' (Quoted by Hellman; Emphasis added). However, the views of eminent scientists in Europe and in the USA have proved to be far out of this opinion, even just the opposite.

In Hellman's view, reliable reporting of past events, which implies that stewardship and the feedback function of accounting is emphasised, is often associated with the need for conservatism. Over time, the IAS have become increasingly future-oriented, pointing out decision usefulness as the primary objective of accounting (IASB Framework; 2006a), and that conservatism seems to have become less of a governing accounting principle (Hellman, 2008, p 72). Other authors like Hendriksen s argue that it is generally stated, that the concept of conservatism is not a postulate of accounting, nor should it be one of the constraints. But in its operational form, as those authors claimed, it serves as a constraint to the presentation of data that may otherwise be reliable and relevant (Hendriksen, 1982 p. 81).

Hellman argues that the normative accounting research tradition went out of fashion in the 1970s, but that critical view on conservatism seems to have been adopted by the US standard setters. Although 
the US APB (1970) acknowledged conservatism as 'a modifying convention of financial accounting,' FASB (1980) does not deliberate on conservatism as one of the desirable qualitative characteristics of accounting information in its framework.

Researchers like Basu ${ }^{9}$ (1997) and Watts (2003a) argued that conservatism has the effect of accelerating the recognition of economic losses, and, reversely, of deferring the recognition of economic gains, that is described by Basu (1997) as 'the asymmetric timeliness of earnings' (ATM). It (ATM) has turned out to be the basis for further research both empirical and theoretical (Watts, 2003b; Ryan, 2006). Authors argued that 'the asymmetric timeliness of earnings', as a feature (property) of conservatism as it is described by Basu, highlighted the intertemporal nature of conservatism - the recognition of unverifiable economic gains or of unrealised economic gains in earnings (and income) is delayed until the uncertain gains turn out to be verifiable or until they are realized. Therefore, in a normal, typical, usual company's life cycle, earnings tend to lag behind the economic income over several accounting periods. In the early stages of the company's life when the investment outlays tend to be higher and revenues lower, earnings tend to be lower than the economic income of the company; however, in the mature stages of the company, when its revenues are higher and more stable, earnings tend to get closer to the economic income or even exceed it (Monahan, 2005; Zhang, 2005). However, it should not be argued that accounting conservatism is not always "conservative" merely because it may lead to lower earnings in one period and to higher earnings in another one. The main purpose of conservatism is to create higher standard or, let's say criteria, of verification for recognition of good news, as a mechanism of dealing with and overcoming economic uncertainties. Thus, the intertemporal properties of earnings are just a consequence of that main purpose of conservatism, rather than the reason for it (Richard, Z. W., 2009).

As to the inherent rule of the inventory evaluation - book value or carrying amount of an inventory should not be written up when market value exceeds cost (cost of acquisition), but it should be immediately written down when market value falls below cost, known as 'the lower of cost and market value' rule, according to the eminent historian R. H. Parker (1969), that practice was firmly established in the $19^{\text {th }}$ century. George $\mathrm{O}$. May claimed that by the time he entered the accounting profession (1892) in England, the rule had already been well established (R. Parker, 1969). This suggests that conservatism probably has been around since the $19^{\text {th }}$ century at the latest, while other researchers argue that the time is even longer. Sivakumar and Waymire (2003) conducted a historical study into the accounting of US railroads at the beginning of the $20^{\text {th }}$ century, using empirical methods. Their study demonstrates that the railroad companies in the US around the turn of the $20^{\text {th }}$ century were not only conservative in methods and accounting policies but that their levels of conservatism also gradually increased, in response to changes in regulations and other factors (Richard, Z. W., 2009). This study provides some of the most considerable and persuasive empirical evidence that conservatism in accounting has existed for a long period of time, resonated the similar conclusion of historians based on mostly non-empirical methods (Richard, Z. W., 2009).

The influence of conservatism on accounting standards is pervasive, and examples can be found in many standards (Richard, Z. W., 2009). Apart from the 'lower of cost and market value' rule which still remains in the US (Richard, Z. W., 2009) and the international accounting standards at present, many rules exist that can be regarded as illustrative examples of conservatism, e.g., the impairment of fixed assets; the expensing of research and development costs, rules as to depreciation and impairment of some assets, provisioning, contingent liabilities, and many others.

Moreover, it is argued (Richard, Zhe Wang, 2009) that 'empirical studies on conservatism in the second half of the $20^{\text {th }}$ century have provided ample evidence that conservatism is a fundamental characteristic of financial reporting in virtually all the developed countries in the world, and also in many developing countries' (Watts, 2003b; Ball et al., 2000; Bushman and Piotroski, 2006; Basu,

\footnotetext{
${ }^{9}$ Basu interprets conservatism as resulting in earnings reflecting 'bad news' more quickly than 'good news' that implies systematic differences between periods of bad news and periods of good news in the timeliness and persistence of earnings. Basu uses firms' stock returns to measure news and finds out that the contemporaneous sensitivity of earnings to negative returns is two to six times that of sensitivity of earnings to positive returns, and that negative earnings changes are less persistent than positive earnings changes. Earnings response coefficients are higher for positive earnings changes than for negative earnings changes, consistent with that asymmetric persistence (Basu, 1997, p. 3-37). Basu argues that conservatism has been established for at least 500 years in Europe, supported by historical evidence that traces the 'lower of cost and market value' rule back to Italy in the 15th century and to France in the 17th century (Littleton, 1941; Emphasis added).
} 
1997; Ball et al., 2003). As we have underline, this is a scientific area of profound research, and many studies have been embarked.

Beginning in the late 1930s, and until the 1980s, conservatism had been criticized by prominent accounting scholars, including Gilman, Hatfield, May, and Paton (Chatfield, 1996). According to Chatfield (1996), the most frequently used arguments against conservatism are: firstly, accounting conservatism is not consistent in that it produces lower income in one period and leads to higher income in another period; secondly, accounting conservatism is arbitrary and gives managers too much discretionary power over reporting, among other problems (by Richard, Z. W., 2009).

However, as Watts (2003a; 2003b) has noted, despite criticisms, not only has accounting conservatism survived numerous accounting reforms, regulations and economic crises in the past century, but also the average degree of accounting conservatism, in the US at least, even (slightly) increased during the past 30 years (Oreshkova, p. 277-292). This claim has been confirmed by empirical studies based on large samples of data from the US and worldwide. For example, with regard to the lower of cost and market rule, Parker observes: "The astonishing thing about the lower of cost and market rule is its ability to survive attack. G. O. May was probably right in suggesting that most accountants are 'content to regard the demonstrated practical wisdom of the rule as outweighing any supposed illogicality'”'(Parker, R.,1969, p. 257, Richard, Z. W., 2009, p. 13).

The inspiration of academics and researchers is to find out the rationale underlying conservatism, and, subsequently, to explain its inherent resilience of criticism even at the present time. "While the search for rational explanations of conservatism is still ongoing, it has already paid big dividends (Richard, Z. W., 2009, p. 13)". Referring to Watts (2003a) and summarizing a large part of the recent developments on the problem, Richard, Z. W. (2009) identified several explanations of conservatism, concerning: the litigation risk and reduction of litigation costs, the debt contracting, the managerial contracting, the political cost, and tax optimization or the tax incentive explanation (Watts, 2003a). These explanations have made conservatism, once unjustifiable in the eyes of Paton and Hatfield, significantly more justifiable (Richard, Z. W., Ibid.).

Due to an existing constraint, it is impossible in the present research to reveal the rich palette of views, considerations, and arguments focused on prudence and 'conservatism.' The literature dedicated to that fundamental problem is vast, since the debate has been ongoing for decades, if not for centuries, and we do not exaggerate. The phenomenon of prudence or 'conservatism' has challenged researchers since the very early periods of the development of accounting as a theory. Thus some academics (e.g. Richard, Z. W., ibid.) acknowledge that many of the arguments have yet to be resolved.

The erosion of prudence in accounting under the influence of international standards setters and other political factors, besides regulatory bodies, has provoked researchers, professional and institutional organizations, experts, practitioners. The international standards setters have attempted to abandon prudence in favor of "neutrality" regarded as a qualitative characteristic of financial statements information since 2006 (IASB, 2006a; FASB, 2006), and even earlier, I suggest. It was claimed that if neutrality was ensured, there would be no downward bias impact on the reported (net) profit or income, even though uncertainty may exist as to the amount of the profit and the question of whether it is realized or not. The motive of upholding that view was that 'prudence' and its inherent 'conservatism,' due to the bias it introduces, appears to be inconsistent with the qualitative characteristics of representational faithfulness. It was argued that neutrality in accountants' behavior will lead to unbiased representation of the underlying economic performance of the entity, thus provide more reliable and relevant information to stakeholders. That way of thinking was very likely to be widely criticized and the ongoing debate has revealed and confirmed all this.

\section{Are "Prudence" and "Conservatism" Synonymous or Not?}

There has been an eclectic for long as well as a wide range of detached opinions. Semantic meanings were accumulated over time. Different authors used one and the same term, but attributed to it different meanings, and interpreted it in a different way. The strong impact of the accounting tradition and culture as well as the lack of linguistic equivalents created and still create difficulties, which impede the more comprehensive and productive debate. Although prudence and 'conservatism' are broadly used by the authors as synonymous, which circumstance, in my view, creates another prerequisite for ambiguity or misconception, we are inclined to support the opinion that a theoretical 
distinction is necessary to be made. It is of importance for achieving precision in defining prudence and in formulating the definition on the grounds of a clear understanding of its essence.

Professor Barker (2015, p. 515) explains that 'conservatism' refers to any method of accounting that leads to book value being less than economic value, while he determines 'prudence' as a specific type of conservatism arising from a 'cautious' response to uncertainty. Barker attains theoretical merit, differentiating between prudence and 'conservatism,' which is needed in setting out distinct theoretical concepts that would otherwise be mingled. His first observation is that conservatism cannot be defined in absolute terms, but it must be defined in relation to something. The consideration is that an outcome can only be described as conservative in comparison with an alternative outcome that is not conservative (and which might be described as 'neutral').

In the case of conservatism, the term 'economic value' is employed as the neutral benchmark. Barker's idea is that a comparison should be made between the estimated worth of the reporting entity in economic terms and the representation of its worth in accounting terms on the balance sheet. "This 'straw man' comparison, in Barker's words, is important in explaining why financial accounting is not a system for the neutral measurement of economic value, and why conservatism is thereby an intrinsic system property." ${ }^{10}$ However, it is not the purpose of annual financial statements to construct models of economic value (Tracey, E., p. 540-542) ${ }^{11}$. Specifically, conservatism is defined as: 'Accounting is conservative if the economic value of an entity's equity exceeds its book value' (Barker, 2015, p. 516).

In Barker's definition, 'economic value' refers to the present value of expected cash flows attributable to holders of equity claims, and 'book value' refers to the carrying amount of net assets. In practice, of course, economic value is an estimate, depending as it does upon the forecasting and discounting of future cash flows. No claim is made that economic value can be 'known' in practice, and in that sense the benchmark of neutrality employed in the quoted research paper is hypothetical, being invoked to identify conceptually the nature of conservatism in accounting.

At this point, it is appropriate to note that Barker's major argument is that financial accounting is inherently conservative, and I think it is apparent that I totally support it. A neutral application of the International Accounting Standards Board's definition of (net) assets leads to book value being less than economic value (Barker, 2015, p. 514). The English professor emphasizes the existence of both conceptual and practical reasons for this, neither of which, in his view, can be explained by an intention to be conservative, by an asymmetry or bias, designed to lead to a conservative outcome.

Financial accounting is not a system for the neutral measurement of economic value, and it is one major observation. Book value and economic value are conceptually different, with conservatism resulting from that difference. This inherent conservatism seems to have been overlooked both by the IASB and by its critics (Barker, 2015, p. 514, p. 515). On the pretext of convergence and under political pressure, after vigorous deliberations, the IASB has removed prudence from the Conceptual Framework (CF) and has been criticised by academics, practitioners and professional organizations. In Barker's viewpoint the challenges to the CF implied by adopting an agency-based, contracting demand for prudent accounting are criticisms of a problem that for the most part does not exist (2015, p. 514).

Strong disagreements exist between the International Accounting Standards Board, on the one hand, and, academics and practitioners, on the other hand, on the question of prudence. On the basis of my previous and current research I tend to believe, that persuasive arguments exist in support of the view that accounting should be conservative. In my view, financial accounting as a system is designed to be a conservative one. Barker also concedes that the research literature is broadly supportive of the notion that accounting should be conservative. Furthermore, he comes up with empirical evidence which suggests a market demand for conservatism as well as an economic theory to explain that demand. With respect to this, the literature is aligned with accounting practice, which has long embodied a prudent approach to financial reporting.

\footnotetext{
${ }^{10}$ Professor Barker argues that IFRS will always result in such differences, not because of applications of conservatism but because of IFRS's definitions of assets and its measurement rules. These make gain recognition less likely than loss recognition and impairment losses more likely than revaluation gains (Richard Barker, 2015).

${ }^{11}$ Tracey, E. (2015). Discussion of 'Conservatism, prudence and the IASB's conceptual framework' by Richard Barker, Accounting and Business Research, 2015, Vol. 45, No. 4, 539-542.
} 
However, in conflict with academics, many institutions and practitioners' perspective, "prudence" was removed from the CF (2010) since the Board did not consider it a desirable quality of the financial reporting information. It should be emphasised that prudence may be thought about as a fundamental principle, as a core principle, as a guiding principle, as a major requirement, as an essential theoretical concept underlying accounting and financial reporting, but it should not be considered a qualitative characteristic of the financial reporting information, as it was previously stated in the Framework. It is deeply erroneous, in my view.

The orthodox view of the financial reporting integral role in the financial system that is of 'bedrock importance to capital markets' is often emphasized (Wallace', UK, 2011) as well as the increased complexity of reporting. As main areas of critical issues in financial reporting are identified valuation, disclosure and comprehension, mostly discussed with reference to the present-day question of whether financial reporting reflects what a business does in reality. It is well known that efforts have been made for the increasing complexity of transactions and business to be reflected in the standards' rules. However, there is now a lack of connection between financial reporting and the entity's business model. For that reason, it is quite logical, the critiques to be primarily linked to the long absence of prudence in the CF that in experts' opinion has been lost as a fundamental concept even in the $\mathrm{UK}^{12}$.

I believe that accounting is a powerful practice that shapes and influences social and economic processes. For instance, Baker and Barbu (2007) point out that accounting has been an integral part of human civilization for 4000 years. Soll (2015) proves that accounting practices have played a remarkable impact on the rise and fall of great nations. The founders of modern economic thought from Adam Smith to Karl Marx - saw accounting as essential to the development of successful economies and modern capitalism. For this reason, Weber (1947) repeatedly insisted on the necessity of studying economy and society together. That view of accounting perceived as a social, political and institutional practice has resulted in a wide range of studies (e.g. Burchell et al., 1985; Napier, 1989; Carnegie, 1993; Dillard et al., 2004). The European Commission also acknowledges that "accounting is not neutral". Indeed, it affects a great variety of stakeholders, not only companies, investors, bankers and auditors, but also citizens, employees and states, since financial information serves as a basis for determining not only economic but also social rights. Accounting, for instance, serves to set the limit for distributable profits, to calculate taxes and to define the public budget to which social welfare is parametrized $^{13}$ (by Palea, 2015).

In my view, conservatism should be understood in a broader sense than prudence. As a core principal that underlies financial accounting and reporting, traditional prudence is considered to comprise some essential rules, which accountants should follow if encouraged to represent the basic economic performance of an entity in a fair-minded, unbiased and unprejudiced manner, and thus provide truthful, sound and verifiable information to stakeholders. Conservatism must be conceived as a wise, prudential philosophy and strategy, the long term benefits of which to entity, state and society should be profoundly considered by each corporate governance and management. It is acknowledged that they, being mostly inspired by extortionately optimistic expectations, and having the prerogatives to influence accountants' decisions, predetermine their behavior, entity's results and performance. As a matter of fact, following the rules of the traditional prudence, accountants having their professional expertise and ethics, strive for the viability, durability and sustainable growth of entities.

\section{The Normative Perspective: An IASB's Exposure Draft Reintroduces Prudence Does the Debate on Prudence End or Does It Not?}

My long-lasting observation of the development of the debate on prudence has given me grounds to argue that the International Accounting Standards Board (IASB) has demonstrated a policy of inconsistency regarding its approach towards 'prudence.' Without difficulties I can provide ample proof for that. Even Macintosh has publicly admitted recently that they, IASB's members, have experienced the influence exerted by the US Financial Accounting Standards Board (FASB). "At the

\footnotetext{
${ }^{12}$ Even the UK Statement of Accounting Practice (SSAP) 2 included the fundamental accounting concepts of going concern, accruals, consistency, and prudence. Then in 2010 the IASB published a revised Conceptual Framework for Financial Reporting which favoured "neutrality" over "prudence" or "conservatism".

${ }^{13}$ Vera Palea and Paolo Pietro Biancone, Which Financial Reporting Standards Does the European Union Need? Working Paper Series, The Department of Economics and Statistics "Cognetti de Martiis".
} 
time - the IASB Vice-Chairman admits, "I didn't think it should have been taken out. But there were people who thought it conflicted with neutrality. There are still people who see things that way ${ }^{\mathrm{ii}}$. But I don't." Further on, Macintosh admits that the influence of the United States Financial Accounting Standards Board (FASB) is less strong than it has been ${ }^{\text {iii }}$ that is slightly compromising, in my opinion (ICAEW Economia, 2015).

Further on, answering the question of why it is worth bother setting prudence back into the Framework (CF), Mackintosh explains that prudence gives people some comfort. He argues that some investors equate prudence with the "true and fair" view, as they believe it will give auditors a tool to help counterbalance management optimism and aggressive accounting policies. Singleton-Green, a manager in ICAEW's Financial Reporting Faculty and his supporters, are quite pleased to see prudence back into the Framework (CF), but others are not, particularly those who see tension between prudence and the concept of neutrality, which, in my view, does not actually exist and this issue is artificially inflated. Professor Stella Fearnley from Bournemouth University (UK) rhetorically questioned opponents and comments further on: "What's neutrality? It's rubbish. Accounts can never be neutral because there are so many judgements in them." As a final point, Mackintosh concludes: "This is an exposure draft. So people can comment again about whether prudence should be in."14

However, on the IASB's meeting as of May $18^{\text {th }}, 2016^{15}$ the Board tentatively decided to confirm its previous decision and belief, namely that the Exposure Draft 'should' propose to reintroduce an explicit reference to the notion of prudence ${ }^{16}$. However, once again the Board admitted, after prolonged persistence, that: '2.18. Neutrality is supported by the exercise of prudence, ${ }^{\text {,17 }}$, which is my thesis and view I have been standing up for since the outset of the debate, specifically, since the debate was triggered. The proposed definition is as follows: 'Prudence is the exercise of caution when making judgments under conditions of uncertainty. The exercise of prudence means that assets and income are not overstated and liabilities and income are not understated. Equally, the exercise of prudence does not allow for the understatement of assets and income or the overstatement of liabilities and expenses' (emphasis refers just to the 'newly' added extension of the definition). I have discussed in my previous research on this problem the reasoning that underlies the change (Oreshkova, 2014, p. 282); the notion (idea) is that such kind of misstatements can lead in future periods either to the overstatement of income or to the understatement of expenses. That was the notion of prudence after the decision to change the definition as of May 21 ${ }^{\text {st }}, 2014$ (IFRS Foundation IASB Meeting, May $2014,20^{\text {th }}$ to $\left.22^{\text {nd }}\right)$.

In the $\mathrm{BC}$ two types of prudence are distinguished: 'cautious prudence,' defined as 'need to be cautious when making judgments under conditions of uncertainty, but without needing to be more cautious in judgments relating to gains and assets than those relating to losses and liabilities. It is in this sense that the Board proposes to reintroduce prudence in the Conceptual Framework; and 'asymmetric prudence,' defined as 'need for systematic asymmetry: losses are recognized at an earlier stage than gains are.' The Board upholds the opinion that the Conceptual Framework should not identify 'asymmetric prudence' as a necessary characteristic of useful financial information.

However, it explains that accounting policies which treat gains differently from losses could be selected in accordance with the proposals in the Exposure Draft only if:

- they are selected in a manner that is not intended to increase the probability that financial information will be received favorably or unfavorably by users of financial statements (i.e. neutral accounting policies are selected); and

- their selection is intended to result in relevant information that faithfully represents what it purports to represent.

\footnotetext{
${ }^{14}$ Ibid, available at: http://economia.icaew.com/en/features/july-2015/perspective-on-prudence

${ }^{15}$ IASB Staff Paper on 'Tentative decisions for the revised Conceptual Framework' on the subject of the 'Proposals in the Exposure Draft Conceptual Framework for Financial Reporting'.

16 On May $21^{\text {st }}, 2014$ the IASB tentatively decided: to reintroduce a reference to prudence in the CF. The description was the exercise of caution when making judgments under conditions of uncertainty. Contrary to the previous description of prudence, it was acknowledged, for the first time, that the exercise of prudence is consistent with neutrality and should not allow the overstatement or understatement of assets, liabilities, income or expenses; secondly, to discuss in the Basis for Conclusions the significance of prudence for prepares in preparing financial statements and for the IASB in setting Standards.

${ }^{17}$ IASB Staff Paper as of January 2017 Effect of Board redeliberations on the Exposure Draft Conceptual Framework for Financial Reporting, Agenda Paper 10D Prudence.
} 
On $18^{\text {th }}$ May 2016 the Board decided to confirm that the revised CF should include a reference to prudence described as the exercise of caution when making judgments under conditions of uncertainty, as proposed in the Exposure Draft. The Board tentatively decided that there is no need to explain in the Basis for Conclusions on the Conceptual Framework that the notion of prudence cannot be used by preparers to override the requirements in IFRS because the Conceptual Framework already includes a statement that it is not a Standard and does not override any specific Standards. In addition, it shouldn't be overlooked that the Board directed the staff to explore further whether and how the Conceptual Framework should acknowledge that asymmetric treatment of gains (or assets) and losses (or liabilities) could be selected if such selection is intended to result in relevant information that faithfully represents what it purports to represent.

The Board tentatively decided (September $22^{\text {nd }}, 2016$ ) that the main body of the revised Conceptual Framework should acknowledge that, in some cases, income may need to be treated differently from expenses and assets differently from liabilities. The Board directed the staff to develop the wording for such an acknowledgement for discussion at a future Board's meeting. On $18^{\text {th }}$ October 2016 the Board tentatively decided that Chapter 2 - Qualitative characteristics of useful financial information of the revised Conceptual Framework should acknowledge that the exercise of prudence does not imply a need for asymmetry - for example, a need for more persuasive evidence to support the recognition of assets than of liabilities or to support the recognition of income than of expenses. Nevertheless, it is admitted that in financial reporting standards such asymmetry may sometimes arise as a consequence of requiring the most useful information.

I tend to argue that with its most recent proposals endorsed as of January 2017, the confusion will reign over everything. The Board differentiates between 'cautious prudence' and 'asymmetric prudence,' purporting that this would contribute to more clarity, or at least would diminish the ambiguity but specialists and academics, including myself, are afraid that the effect will be just the opposite. One observation is, that way the Board will prescribe the appropriate level and type of prudence. Regarding this reasoning and the above-mentioned proposals IASB is once again criticized because of academic and institutional disagreements.

Authoritative professional institutions like ICAEW thoroughly comment on that issue claiming that the conflict between the CF and the essentials of some IAS/IFRS will be intensified and that is true. The view of AAT is also worth to be supported. They believe that while a principles-based approach to standards prevails, prudence provides a greater degree of assurance than neutrality does, and it is supportive of the inclusion of prudence within the CF.

However, the conceptual idea of prudence is embedded into already existing IAS/IFRS to a certain extent and in different ways; the notion of the so-called by the IASB 'asymmetric prudence', for example, can be seen in the standards themselves; as per IAS 11 Construction contracts, losses on a contract are recognised as soon as they are foreseen, i.e. predicted or expected; specifically, when it is (highly) probable total contract costs to exceed total contract revenue, the expected loss should be immediately recognised as an expense.

In this respect, some disclosure requirements seem to be prudential. As per IAS 11, an entity discloses any contingent liabilities and contingent assets in accordance with IAS 37 Provisions, contingent liabilities and contingent assets. It is specified that contingent liabilities and contingent assets may arise from such items as warranty costs, claims, penalties or possible losses. For example, IAS 37 requires disclosure, in specified circumstances, of major assumptions concerning future events affecting classes of provisions. IFRS 13 Fair Value Measurement requires disclosure of significant assumptions, including the valuation technique(s) and inputs the entity uses when measuring the fair values of assets and liabilities that are carried at fair value.

In compliance with IAS 37 Provisions, contingent liabilities and contingent assets full provision must be made for all the expected losses on onerous contracts, regardless of whether these items have been delivered or not. IAS 37 prescribes asymmetric treatment of contingencies as it differentiates between positives and negatives. Contingent assets can only be recognized if their receipt is virtually certain, whereas contingent liabilities must be recognized if the outflow of resources is more likely than not.

The IFRS criteria prevent recognition of items such as internally generated intangibles (for example, internally generated goodwill) or provide greater thresholds of probability regarding some items 
recognition as it is the case with capitalization (or not) of development costs. Non-financial and noncurrent assets are initially recognised at historical cost, and the basic rule is that a decline in value (carrying amount) must be recognised immediately as an impairment loss for the period over which the entity incurred the loss, whereas increases in values are not recognised until the asset is sold (in case that the cost model of valuation is preferred as a component of the entity's accounting policy).

The depreciation charge for each period should be recognized in profit or loss unless it is included in the carrying amount of another asset, while the revaluation surpluses (excesses) are treated in a more prudential manner, as components of other comprehensive income ${ }^{\mathrm{iv}}$. Some disclosure requirements as to the notes, designed to reveal the policies relating to sensitivity of evaluations to changes in assumptions, can be seen as prudential. The so-called by the Board 'asymmetric prudence' can be seen in variable consideration in IFRS 15 Revenue from contracts with customers. However, in the area of financial instruments, there is basically no asymmetric recognition.

No doubt that there can be found many examples of non-prudential approach in the IAS/IFRS. For instance, provisions shall not be recognised for future operating losses, since future operating losses do not meet the definition of a liability (in paragraph 10, IAS 37) and the general recognition criteria set out for provisions (in paragraph 14, IAS 37); this is a big question and a key issue; the reasoning is that an expectation of future operating losses is an indication that certain assets of the operation might have been impaired; and what's next, an entity should test these assets for impairment under IAS 36 Impairment of assets, the application of which is highly complicated and creates problems in practice.

ACCA's members, whose view is always interesting, also do not agree with the way prudence has been dealt with in paragraph 2.18 . The approach to prudence regarded as 'a quality (caution in the face of uncertainty) which should be followed in the preparation of financial statements', is risky, ACCA ${ }^{\mathrm{v}}$ argues as it encourages earnings management by giving companies the freedom to reduce profits by applying prudence in the preparation of the accounts when it is convenient.

\section{Further Considerations and Inferences}

In general, the policy of pursuing prudence in accounting, especially in an enterprise operating in the real (non-financial) sector of the economy, can manifest itself in a number of management decisions, which, different in nature as they might seem, are targeted at achieving the same goal - not to overstate neither understate the value(s) of (net) assets of the entity. Keeping up with that way of thinking we can give a lot of examples including primarily the following:

- Well-grounded classification and/or re-classification of the different assets and liabilities in interrelationship with the opportunity of choosing the model of valuation, and of allowing change it if necessary (only in case the alternative model turns out to be the most appropriate);

- Searching for a sound judgment on the matter of the useful life of each depreciable asset supported by its most appropriate estimation;

- A reasonable choice of the method or methods of depreciation based on thorough preliminary analysis;

- Allowing for changes of a useful life and/or a method of depreciation as an exception in order to observe consistency (only if these changes are necessary for the faithful representation);

- Sound determination, including the use of unbiased expert assessment, of the residual values of all depreciable assets;

- Well-grounded judgement as to the presence of all criteria for recognition of an existing obligation as a provision; this is an important issue since if one of the criteria is not met, a disclosure of a contingent liability should be made unless the possibility of an outflow of resources embodying economic benefits is remote; and this is in regard to the necessity of providing sufficiently transparent information in the supplementary notes in order to enable users to understand the nature, timing, and amount of the provisions;

- Provisioning which should be more future-oriented rather than past-oriented;

- Capitalization of research and development expenditure only if it is certain that the prescribed criteria have been cumulatively met;

- An urge for recognition in the financial result for the reporting period of sufficiently highly liquid profits primarily; 
- Creation and maintenance of sufficient highly liquid reserves taking into consideration the scale of the enterprise, the nature of its operating activities and all inherent risks to which it could be exposed at present or in the future;

- Identifying precisely the amount of borrowing costs that are eligible for capitalization in relation to acquisition, construction or production of assets adequately determined as qualified;

- Sensible choice of adequate approaches to the recognition of revenues; it is well known that in the process of applying the entity's accounting policies, management makes various judgements, apart from those involving estimations, that can significantly affect the amounts recognised as items of the financial statements; for example, professional judgements are needed for determining whether particular sales of goods are, in substance, financing arrangements, and if so, they do not give rise to recognition of revenue;

- Continuous observation of the process of collecting receivables from the contracting parties; determining a criterion (threshold) for the amount of receivables in arrears embodying high risk, beyond which the supplies to the counterparty should be suspended;

- Substantiated classification of all lease contracts (particularly in cases of uncertainty and necessity of judgment as to whether the contract in its nature is a finance lease or operating lease (until the effective date of the new IFRS 16 Leases);

- And many more to follow.

For now, we shall not comment opinions, which do not support the idea of 'neutrality' in accounting, and not consider it a qualitative characteristic of financial statements information. However, we do not argue that this specific understanding is devoid of good sense or judgment, rather just the opposite.

In my opinion strong arguments exist in support of the thesis I maintain not from that moment: the use of fair value valuation raises an important problem with respect to the "going concern principle" and "the liquidation basis" of accounting. Under the going concern basis, the assets are or should be treated together as a unit, as the essential elements for implementing the business model, and as such they are only considered from the point of view of their utility as opposed to their sales values. The "going concern principle" supports measurement at historical cost and justifies the existence of goodwill that comprises and therefore recognizes a part of the unrealized profits associated with the acquired assets whereas under the liquidation basis, this unit is broken down into a series of individual assets that can be liquidated separately. The liquidation principle supports fair value measurement of each individual asset but appears inconsistent with the recognition of goodwill. However, the IAS, developed and issued by the IASB, seem to reflect a certain opportunism, in which they allow 'fair value' and 'goodwill' to coexist. It is also worth acknowledging something else, which is important; even the most accurate and detailed descriptions or definitions would be inadequate if the necessity of exercising policy of prudence in accounting were not perceived as a priority or as an essential prerequisite for resilience and viability of the enterprise, as well as a vital social necessity.

I confidently maintain the view that financial accounting is a powerful tool for sharing the wealth among all members of society, for its fair distribution between present and future generations, between short- and long-term perspectives. Unfortunately, through the accounting standards high priority has been given for many years to the short-term rather than the long-term performance. From an academic standpoint I argue that criticism from researchers and other specialists are based on sufficiently reasonable arguments. It reveals significant management weakness and errors made under the influence of short-sighted policies and decisions aimed at ensuring the best results of the present at any cost without particular concern for the future that the CF and IFRS apparently have been allowing, in many cases in conflict with the philosophy of prudence in accounting. In my view, many empowered people belonging to various managerial, regulatory and other authorities of different hierarchical levels from many countries across the world are responsible for admitting grave errors, and having unreasonable behavior as officials, executives, administrators etc. The need for a paradigm shift in financial reporting has been increasingly discussed by leading scientists in Europe and overseas.

\section{Conclusions}

My belief is that the principle or the concept of prudence, not just the term even less 'the word', should be considered to be of the highest priority among all the traditional accounting principles as it 
has been inherent in the philosophy and unique technique of double-entry procedure and accounting ever since its inception as a social practice, later gaining the status of science. In my view, prudence is consistent with neutrality rather than in antagonism with it. It is hard for me to agree that the foundational idea of prudence, if it is correctly understood, is incompatible with neutrality as it was previously stated.

In my view, the re-introduction of prudence would not obscure the transparency of financial reports information nor would it weaken their ability to represent the economic essence of a transaction or process in a credible way.

'Prudence' should be restored into the CF and its importance as an integral part of financial accounting and reporting essentials should be emphasized. The description should be sufficiently distinct and explicit to avoid misunderstanding or misinterpretation. A thorough description would contribute to greater clarity and consistency. If not, the CF prescriptions would not comply with the essence of a number of standards which embody the conceptual idea of prudence (for example, IAS 36 Impairment of Assets, IAS 16 Property, Plant and Equipment, IAS 37 Provisions, Contingent Liabilities and Contingent Assets, IAS 38 Intangible Assets, IAS 2 Inventories etc.). If restored, it would provide for a reasonable and balanced judgement under conditions of uncertainty and would contribute fair estimates to be achieved in the process of valuation.

My earlier hypothesis for the presumable existence of types of conservatism has been confirmed. The understanding varies across countries, accounting systems and cultures. We tend to consider that despite its decades-long development, convergence has not significantly advanced. The major differences still exist due to the clash between traditions and long-lasting influences (historical, legal, political, institutional, economic, social, cultural, linguistic, psychological etc.) under which the accounting models (for example, Anglo-Saxon or Continental) have developed. The prevailing factors contribute to the establishment of approaches which have dominated the accounting model. The principle of prudence is closely related to the European continental style of governance, the traditional manner of representing companies' activity which is based on the long-term vision of business life. Scientists claim that the assumed conceptual superiority of IFRS reflects a strong Anglo-American bias in describing continental European accounting models and reasonably question the assumption that the Anglo-American accounting model is superior to other accounting paradigms ${ }^{18}$.

The CF contains the basic concepts, assumptions, key definitions etc., and the way they are interpreted in practice impacts the quality of financial statements information. It is explicitly stated in the CF that it is not a standard, hence a comprising part of the international normative base, therefore of the regulations as regards the financial reporting in the EU member-states and other jurisdictions, and cannot override any standard; However, the Framework is assigned the role of a political chart which is supported and endorsed by all the member-states and their political leaders; so, the problem regarding its relevant importance and conformity to accounting standards should not be compromised. However, the CF is an introduction or a prelude to the IAS/IFRS and for that reason it is illogical for the core concepts not to be consistent with basic precepts, embodied in the accounting standards.

The moral of the probably subsiding crisis is that transparency, based on commonsense, optimally combined with prudence, must become a priority in financial reporting and the presentation and disclosure of relevant financial and non-financial information, both historical and prospective. For that purpose, the approaches, models and rules for recognition and measurement of assets, liabilities and capital components, of costs and revenues/income must be designed, developed and implemented in the spirit of this underlying philosophy.

First of all, we need to restore confidence in the quality of corporate reporting and the information it provides as well as to reestablish trust in the respective bodies and people, authorized to be responsible for its credibility and verifiability.

\section{References}

Accounting Principles Board (APB). (1970). Accounting Principles Board Statement No. 4, Basic Concepts and Principles Underlying Statements of Business Enterprises (New York: AICPA).

\footnotetext{
${ }^{18}$ Heidhues, E. and Patel, C. (2011), Anglo-American Accounting Biases in the Rush towards Convergence: The Case of Germany, Macquarie University, Australia.
} 
Ahmed, A. S., K. B. Bruce, R. M. Morton, and M. Stanford-Harris. (2002).The role of accounting conservatism in mitigating bondholder-shareholder conflicts over dividends policy and in reducing debt costs. The Accounting Review 77(4), pp. 867890

Artsberg, K., and Nilsson, C. (1993). Accounting and taxation: examining the difference between state and market claims on accounting, in: K. Artsberg, A. Loft and S. Yard (Edition) Accounting Research in Lund, pp. 25-41 (Lund: Lund University Press).

Association of Chartered Certified Accountants (ACCA). (2012). The future of financial reporting: global crisis and accounting at a crossroads, A discussion paper on the British Accounting and Finance Association's Financial Accounting and Reporting Special Interest Group (FARSIG) Symposium, January 7th, 2011.

Autorité des Normes Comptables (ANC). (Décembre 2010). First Autorité des Normes Comptables (ANC) Symposium on Accounting Research.

Ball, R. and L. Shivakumar. (2005). Earnings quality in UK private firms: Comparative loss recognition timeliness. Journal of Accounting and Economics 39(1), 83-128.

Barker, R. (2001). Determining Value: Valuation Models and Financial Statements. Financial Times-Prentice Hall.

Barker, R. (2004). Reporting Financial Performance. Accounting Horizons, 18(2), pp. 157-172.

Barker, R. (2010). On the Definitions of Income, Expenses and Profit in IFRS. Accounting in Europe, (2), 1-14.

Barker, R. (2015). Conservatism, Prudence and the IASB's Conceptual Framework (P.D. Leake Lecture). Accounting and Business Research, 45(4), pp. 514-538

Barker, R. and McGeachin, A. (2015). Is the IASB Consistent on Conservatism? An Evaluation of the Concept and Practice of Conservatism in IFRS.' Abacus, 51(2):169-207.

Barker, R., \& McGeachin, A. (2013). Is the IASB Consistent on Conservatism? An Evaluation of the Concept and Practice of Conservatism in IFRS: Working Paper, Oxford University, Oxford.

Basu, S. (1997). The Conservatism Principle and the Asymmetric Timeliness of Earnings. Journal of Accounting and Economics, 24 (1), 3-37.

Beaver, W. and Ryan, S. (2000). Biases and lags in book value and their effects on the ability of the book-to-market ratio to predict book return on equity, Journal of Accounting Research, 38, pp. $127-148$.

Beaver, W.H. and S.G. Ryan. (2004). Conditional and unconditional conservatism: concepts and modeling, Stanford University and New York University.

Cooper, C. (2015). Accounting for the fictitious: a Marxist contribution to understanding accounting's roles in the financial crisis, Critical Perspectives on Accounting, Volume 30, p. 63-82.

Ernst \& Young. (2006). Ernst \& Young (2006) IFRS: Observations on the Implementation of IFRS.

European Commission, Commission Regulation (EC) No 1126/2008 as of 3 November 2008 adopting certain international accounting standards in accordance with Regulation (EC) No 1606/2002 of the European Parliament and of the Council.

Fearnley, S. \& Sunder, S. (2005). The headlong rush to global standards. The Financial Times, p. 14.

Fearnley, S. (2009). Restore prudence to accounting. The Financial Times, March.

Fearnley, S. and Sunder, S. (2012). Global accounting rules - an unfeasible aim. The Financial Times, June 3rd.

Feltham, J. and Ohlson, J. (1995). Valuation and clean surplus accounting for operating and financial activities.

Contemporary Accounting Research, 11(2), pp. 689 - 731.

Financial Accounting Standards Board (FASB). (1980). Statement of Financial Accounting Concepts No. 2: Qualitative Characteristics of Accounting Information. Norwalk, Connecticut: Financial Accounting Standards Board.

Financial Accounting Standards Board (FASB). (1980). Statement of Financial Accounting Concepts No. 2: Qualitative Characteristics of Accounting Information.

Financial Accounting Standards Board (FASB). (2006). Preliminary Views: Conceptual Framework for Financial Reporting: Objective of Financial Reporting and Qualitative Characteristics of Decision-Useful Financial Reporting Information, Financial Accounting Standards Board.

Forrester, D. A. R. (1993). Eugen Schmalenbach and German Business Economics (New York and London: Garland Publishing Inc.).

Gebhardt, G., Mora, A., \& Wagenhofer, Alfred. (2014). Revisiting the Fundamental Concepts of IFRS. Abacus: A Journal of Accounting, Finance and Business Studies, 50 (1), 107-116.

Haller, A. (2003). Accounting in Germany in: P. Walton, A. Haller and B. Raffournier (Editions) International Accounting, 2nd edition (Thomson Learning).

Haller, A. and Eierle, B. (2004). The adoption of German accounting rules to IFRS: a legislative balancing act, Accounting in Europe, 1(1), pp. 27-50.

Heidhues, Eva and Patel, Chris. (1988). Anglo-American Accounting Biases in the Rush towards Convergence: The Case of Germany.

Hellman, N. (2008). Accounting Conservatism under IFRS. Accounting in Europe, Vol. 5, No. 2, pp. 71-100.

Hendriksen, E. S. (1982). Accounting Theory, 4th edition (Homewood: Irwin). 
Hoogervorst, H. (2012). Dispelling myths about IFRS: Introductory remarks by Hans Hoogervorst, Chairman of the IASB, A Speech at the Opening of the IFRS Foundation Regional Office in Asia-Oceania in Tokyo.

Hoogervorst, H. (2012). The Concept of Prudence: dead or alive? FEE Conference on Corporate Reporting of the Future. Brussels, pp. 1-7.

Hoogervorst, H. (2013). The search for consistency in financial reporting. A Speech at the CeFARR, E\&Y Cass Business School, London, pp. 1-8.

Hoogervorst, H., Clark, P. \& Knubley, R. (2014). IFRS Foundation, International Financial Reporting Standards Conceptual Framework, December 3rd.

Huerta de Soto, J. (2009). Translated by Melinda A. Stroup. Money, Bank Credit, and Economic Cycles, (2nd Edition). Ludwig von Mises Institute. Auburn Alabama.

IASB IFRS Foundation (July 2013). Discussion Paper (DP/2013/1) 'A Review of the Conceptual Framework for Financial Reporting'.

ICAEW, Economia (2015); available at: http://economia.icaew.com/en/features/july-2015/perspective-on-prudence. IFRS Foundation IASB Staff Paper Conceptual Framework: High level overview of feedback on the Discussion Paper (2014).

IFRS Foundation IASB, IASB Meeting, Staff Paper as of September 2016, Project Conceptual Framework, 'Asymmetry in treating gains and losses', IFRS Agenda ref 10D.

IFRS Foundation IASB: IASB Meeting Staff Paper as of February 2017 Project Conceptual Framework.

Imam, S., Barker, R. and Clubb, C. (2008). The Use of Valuation Models by UK Investment Analysts. European Accounting Review, 17(3), pp. 503-535.

Institute of Chartered Accountants in England and Wales (ICAEW) Economia, (July, 2015). Perspective on prudence, Lesley Meall looks at the debate.

International Accounting Standard Board (IASB) (January 2017). IASB Staff Paper, Effect of Board redeliberations on the Exposure Draft Conceptual Framework for Financial Reporting Proposals (the Exposure Draft), The International Accounting Standard Board's (the Board) tentative decisions.

International Accounting Standards Board, International Accounting Standards Committee Foundation. International Accounting Standards Board (2006a) Preliminary Views on an improved Conceptual Framework for Financial Reporting: The Objective of Financial Reporting and Qualitative Characteristics of Decision-useful Financial Reporting Information. Discussion Paper, July 2006 (London: International Accounting Standards Committee Foundation).

International Accounting Standards Board, International Accounting Standards Committee Foundation. International Accounting Standards Board (2006b) International Financial Reporting Standards 2006 Bound Volume (London: International Accounting Standards Committee Foundation).

Koleśnik, K. (2013). The Role of Culture in Accounting In the Light of Hofstede's, Gray's and Schwartz's Cultural Dimensions Theories - A Literature Review, Financial Internet Quarterly „e-Finanse” vol. 9, No. 3, pp. 33-41.

Lara, J. M. G. and Mora, A. (2004). Balance sheet versus earnings conservatism in Europe. The European Accounting Review, 13(2), pp. 261-292.

Mackintosh, Ian. (13th August 2014). IFRS Foundation Conference, Johannesburg: Are truly global standards achievable? Mackintosh, Ian. (23rd June, 2014). IFRS Foundation Conference, London: Turning back the clock?

Milanova, E. (2012). Accounting aspects of anti-cyclical policy of the banks in Bulgaria”, Jubilee International Scientific Conference: 'Crisis and Economic Growth', UNWE, Sofia, University Press, pp. 111-119.

Narayanan, S. and Burkart, M. (2005). The Role of Accounting Conservatism in a well-functioning Corporate Governance System, pp. 1-16. URI: https://mpra.ub.uni-muenchen.de/id/eprint/4458

Oreshkova, Hr. (2014). Current Fundamental Issues of Corporate Financial Reporting: Past Lessons in Favor of the Future. Global Business Conference 2014 Proceedings: Questioning the Widely-held Dogmas, Dubrovnik, Innovation Institute, Zagreb, pp. 277-291.

Oreshkova, H. (2013). The crisis and the future of financial reporting: Global financial reporting standards - reality or utopia, UNWE: Economic Alternatives, 2013, Issue 2, pp. 50-75.

Paton, W. and Littleton, A. C. (1940). An Introduction to Corporate Accounting Standards (American Accounting Association Monograph No. 3).

Penman, S. H. and Zhang, X-J. (2002) Accounting conservatism and the quality of earnings, and stock returns, The Accounting Review, 77(April), pp. 237 - 264.

Quire, C. D. (1965). Book review of Eugen Schmalenbach, Dynamic accounting, The Accounting Review, 40 (April), pp. 511-513.

R. Z. Wang. (2009). Accounting conservatism, Victoria University of Wellington, A thesis for the degree of Doctor of Philosophy in Accounting, pages 1-198.

http://researcharchive.vuw.ac.nz/xmlui/bitstream/handle/10063/1321/thesis.pdf?sequence $=1$

Richard, J. (2005), “L’Union Européenne mise aux normes Américaines: Une comptabilité sur mesure pour les actionnaires”, Le Monde diplomatique, Bulgares édition, no. 1, pp. 24-25.

Richard, J. The IFRS are both obsolete and dangerous. University of Paris Dauphine. CREFIGE: IFRS... Jacques Richard. 
Ryan, S. G. (2006). Identifying conditional conservatism. European Accounting Review, 15(4), pp. 511-525.

Schmalenbach, E. (1959). Dynamic Accounting, translation by G. W. Murphy and K. S. Most of the 12th edition of Dynamische Bilanz (London: Gee and Company (Publishers) Ltd).

Shroff, Pervin K., Venkataraman, R., \& Zhang, S. (2004). The Conservatism Principle and the Asymmetric Timeliness of Earnings: An Event-Based Approach. University of Minnesota Working Paper, 1-50.

Sterling, R. R. (1967) Conservatism: the fundamental principle of valuation in traditional accounting, Abacus, 3(2), pp. 109132.

Sterling, R. R. (1970). Theory of the Measurement of Enterprise Income: University of Kansas Press.

Tracey, E. (2015). Discussion of 'Conservatism, prudence and the IASB's conceptual framework' by Richard Barker, Accounting and Business Research, Vol. 45, No. 4, 539-542.

Vera Palea and Paolo Pietro Biancone, 2015, Which Financial Reporting Standards Does the European Union Need? Working Paper Series, The Department of Economics and Statistics "Cognetti de Martiis" publishes research papers authored by members and guests of the Department and of its research centers.

Watts, R.L., (2003a). Conservatism in accounting Part I: Explanations and implications. Accounting Horizons, 17 (3), $207-$ 221

Watts, R.L., (2003b). Conservatism in accounting Part II: evidence and research opportunities. Accounting Horizons, 17 (4), 287-301.

Zorgniotti, J. The Chairman of the Superior Council of the Ordre des experts-comptables (OEC), (December 2010). Turn accounting into a meaningful art', The First Symposium on accounting research, organised by the Autorite des normes comptables (ANC), Paris, 2010

\section{Key Abbreviations}

Accounting Principles Board (APB); American Institute of Certified Public Accountants (AICPA); Association of Accounting Technicians (AAT); Association of Chartered Certified Accountants (ACCA); Autorité des Normes Comptables (ANC); Basis for Conclusions (BC); Conceptual Framework for Financial Reporting (CF); European Commission (EC); European Financial Reporting Advisory Group (EFRAG); Expected loss Model (ELM); Financial Reporting Council (FRC); Incurred-loss Impairment Model (ILM); Institute of Chartered Accountants in England and Wales (ICAEW); Institute of Chartered Accountants of Scotland (ICAS); International Accounting Standards (IAS); International Accounting Standards Board (IASB); International Financial Reporting Interpretations Committee (IFRIC); International Financial Reporting Standards (IFRS); U.S. Securities and Exchange Commission (SEC); US Financial Accounting Standards Board (US FASB); US Generally Accepted Accounting Principles (GAAP);

\footnotetext{
i Pauline Wallace, Head of Public Policy and Regulatory Affairs at PricewaterhouseCoopers, reasonably argues that there is increasingly voluminous reporting relating to mandatory disclosure, but limited disclosure in key areas such as financial risk and volatility. 'With a growth in the volume of reporting and its complexity coupled with a lack of comparability between different GAAPs (UK versus US in a non-uniform world), there are questions over the usefulness of reporting to stakeholders and their comprehension of what is reported, leading to a consequently reduced reliance on financial statements.'

ii 'Prudence also seems inherently inconsistent with neutrality, so, prudence cannot be incorporated within that concept', in the ACCA's view, and we definitely cannot agree with that understanding specifically.

iii Mackintosh (2015) admitted that 'when prudence was taken out, the concepts were being developed jointly. The US didn't have it and didn't see why it should be in there, so that probably swayed the IASB at the time. After the Framework became an IASB-only project, a door was opened for prudence to walk back through" (Mackintosh, 2015; Quoted by Lesley Meall).

${ }^{\text {iv }}$ For example, if an asset's carrying amount is increased as a result of a revaluation under the revaluation model the increase must be recognised in other comprehensive income and accumulated in equity under the heading of revaluation surplus. However, the increase must be recognised in profit or loss to the extent that it reverses a revaluation decrease of the same asset previously recognised in profit or loss. If an asset's carrying amount is decreased as a result of a revaluation, the decrease must be recognised in profit or loss. However, the decrease must be recognised in other comprehensive income to the extent of any credit balance existing in the revaluation surplus in respect of that asset. The decrease recognised in other comprehensive income reduces the amount accumulated in equity under the heading of revaluation surplus.

' In the ACCA's view, when there is significant uncertainty with regards to an asset or a liability then that should be reflected in the risk premium or adjustment made in reaching either an assessment of any impairment of a historical cost element or one at fair value. It is often the case that external parties may place more weight on downside rather than on upside risks in valuing assets and liabilities. ACCA see an important role for what could be termed prudence in standard setting, particularly in the possibility that there should in some cases be asymmetric recognition of assets and liabilities and gains and losses. This possibility of asymmetry is confirmed in the Basis of Conclusion but being so important, in their view, it should be dealt with in the CF itself as a possibility (not a necessity) in Chapter 1 and under the recognition criteria in Chapter 4.
} 